DOI 10.22455/2619-0311-2018-1-236-256

УДК 821.161 .1

\title{
Людмила Сараскина
}

\section{Перемена мест и судеб}

(Э. Золя, А. Пушкин и Ф. Достоевский на британском экране) $)^{1^{*}}$

\section{Ludmila Saraskina}

\author{
Changing Places and Destinies \\ (Émile Zola, Alexander Pushkin, and Fyodor Dostoevsky \\ in British Cinema)
}

Об авторе: Людмила Ивановна САРАСКИНА, доктор филологических наук, главный научный сотрудник Государственного института искусствознания. Живет в Москве. E-mail: l.saraskina@gmail.com

About the author: Ludmila I. SARASKINA, Doctor of Philology Principal research fellow State Institute of Art Studies. Lives in Moscow. E-mail: 1.saraskina@ gmail.com

Аннотация. В статье анализируется категория места действия в качестве структурного элемента художественного произведения. Место действия, или пространственную локализацию описываемых событий, принято называть частью сеттинга - среды, где протекает действие. Для эпического жанра это не только необходимый фон развития событий, но и (составная?) часть образа героев. История кинематографических переделок литературного произведения показывает, что категория места действия так же подвижна и текуча, как и категория времени. Кинематограф, нацеленный на экранизации, часто страдает охотой к перемене мест. Обретения и потери в каждом случае требуют подробного анализа, однако можно предварительно сказать, что тогда, когда проблематика литературного произведения выходит далеко за рамки тех мест, где протекает действие, там сеттинг уходит на второй план.

1 * Глава из завершающейся книги: Сараскина Л.И. Литературная классика в соблазне экранизации: столетие перевоплощений. 
Проблема места и времени действия рассмотрена на примере недавних британских экранизаций трех литературных произведений: романа Э. Золя «Дамское счастье», романа А.С. Пушкина «Евгений Онегин», повести Ф.М. Достоевского «Двойник». Понять, что утеряно и что приобретено в осмыслении этих текстов при их экранном осовременивании и перемене места действия, - значит дать адекватную оценку одноименным киновоплощениям.

Ключевые слова: место действия, сеттинг, экранизация, осовременивание, осмысление, обретения, потери.

Abstract. The paper analyses the category "place of action" as a structural element in a work of art. The place of action, that is the spacial localisation of the events described or otherwise presented in a work of art, is usually considered part of the setting, that is the whole milieu where the action takes place. For epic genres, the place of action is not only the necessary background of the unfolding events, but also a constituent part of the characters. The history of screen versions of literary works shows that the place of action may be as mutable and fluid as the time of action. The cinema which deals with screen versions is very often obsessed with what A. Pushkin in "Eugene Onegin" called "a desire for changing places". Gains and losses in each particular case require a detailed analysis, but, in a preliminary way, we may say that when the problems raised by a particular literary work transcend the limits of the localities where the action takes place, the significance of the setting deminishes.

In this paper, the problem of "place (and time) of action" is considered through analysing three recent British screen versions of the three literary works: Émile Zola's novel "Au Bonheur des Dames" (“The Ladies' Delight”, 1883), Alexander Pushkin's novel "Eugene Onegin" (1823-1831), and Fyodor Dostoevsky's short novel "The Double" (1846). To appraise adequately these screen versions, we have to understand what has been gained and what has been lost in the interpretations of the original literary texts after their contemporising and changing the places of their action.

Key words: place of action, setting, screen version, contemporising, interpretation, gains, losses. 
Если время действия литературных произведений при переносе их на экран легко меняют свою определенность - происходит так называемое осовременивание - то тем более подвержены трансформациям место действия (размещение действия в других географических координатах), пейзажи, портреты, детали интерьера, предметы одежды и быта. Не вызывает сомнения, что в романе Ф.М. Достоевского «Преступление и наказание» или в его повести «Белые ночи» образ Петербурга имеет огромное значение для понимания душевного состояния Раскольникова и настроения безымянного Мечтателя. Но если события «Преступления и наказания» или «Белых ночей» перенесены на столетие-полтора позже и получили прописку в другой стране, другой культуре, среди народа другой национальности и веры, образ Петербурга исчезает из киноповествования, и его место занимает другое пространство, с другой символикой, другими опознавательными знаками.

Вещный, предметный мир картины-адаптации не может существовать отдельно от трактовки художественного образа. Если костюм героини откровеннее общепринятого, или ее мимика менее сдержанна, чем позволяют правила приличия ее среды, это значит, что не в костюме и не в мимике дело, а в характере героини, какой ее увидел режиссер и какой ее сыграла актриса. Вещный мир произведения создает плацдарм, на котором разворачиваются события. Невозможно представить себе сериал «Гарри Поттер» без атрибутов Хогвартса: мантий, волшебных палочек, метел, колб с зельем, игры в квиддич, а фильм «Обломов» - без длинного домашнего халата героя. Детали в литературном тексте и в кино-адаптации чрезвычайно информативны, неслучайны и обладают большим смыслом. Деталь - это не обязательно предмет: деталь, подробность может проявиться в поведении, в реакции на события, в интонации, в расстановке мебели или времени обеда персонажа. Главное - уметь считывать информацию и, переводя литературу на язык кинематографа, найти соответствующий эквивалент, понимая, что деталь может раскрыть образ, а может его пригасить или убить.

Задача экранизаторов в этом случае - найти адекватные эквиваленты пейзажей, костюмов, деталей интерьера, с тем, чтобы они соответствовали характеру героев, сути конфликта, сюжетным ходам. Выяснить, меняют ли изменения времени и места действия структуру образов и содержание произведения - это и есть задача «осовремененной» экранизации. Нельзя рассчитывать, что взыскательные зрители, а тем более зоркие критики не заметят несоответствия образных элементов, деталей эпохи, декораций. 


\section{I}

Место действия - структурный элемент художественного произведения, определяющий пространственную локализацию описываемых событий. Место действия определяют как часть сеттинга ${ }^{1}$ - то есть той среды, в которой протекают события.

Место действия имеет различное значение для жанров и видов литературы. Для лирической поэзии оно не важно, но в поэзии описательной требует подробного представления. Для эпического жанра это важнейшая категория, и не только необходимый фон развития событий, но и часть образа героев. Так, Татьяна Ларина - деревенская барышня и Татьяна Ларина - столичная светская замужняя дама совершенно по-разному выглядят, ведут себя и воспринимаются окружающими.

Еще большее значение место действия имеет в драме, где получает физически ощутимую наглядность в виде декораций, конструкций, трехмерной сценической площадки. Если роман лишь рассказывает о месте действия, описывает его, то драма должна так или иначе показать его зрителю. Достижения техники сцены дают современному драматургу возможность включать в сеттинг пьесы элементы кинематографа, исторической хроники, визуальных документальных вкраплений, радио, телеэкрана и т.п. Но не техника сцены определяет стиль пьесы - драматурги лишь используют эту технику как средство выражения своего художественного замысла. К тому же театральная сцена имеет вполне внятные, жестко очерченные границы технических возможностей, которые с успехом преодолеваются в кинематографе, с его поистине безграничными ресурсами в изображении любого пространства, любой среды и обстановки.

История кинематографических переделок литературного произведения много раз успела показать, что категория места действия так же подвижна и текуча, как и категория времени. Точно так же, как действие античной хроники может быть перенесено из V века до н.э. в нынешнее время, в XXI век («Кориолан»), точно так же события романа Достоевского обнаруживаются не в Петербурге середины XIX века, а в Алма-Ате сегодняшних дней («Студент»).

Можно с уверенностью сказать, что кинематограф, вплотную занятый экранизациями, часто страдает (или вдохновляется!) охотой $к$ перемене

1 Се́ттинг (от англ. setting - «обстановка», «помещение», «установка», «оправа»). Термин «сеттинг» применительно к литературному произведению стали употреблять относительно недавно. 
мест. Так, события шекспировского «Гамлета» происходят в Дании, в конце XVI века, причем в трагедии представлена версия эпизода из «темного времени», впервые рассказанная в исландской хронике XII века Саксоном Грамматиком, автором «Истории датчан». Однако кинематограф дерзко переносит «Гамлета» и Гамлета и в Японию, и в Турцию, и в Финляндию, размещая трагедию и ее героя и в XX, и в XXI веке. Петербургский роман Достоевского «Идиот» из середины XIX столетия приспосабливается к реалиям Японии середины XX столетия или Индии 1990-х годов. Обретения и потери в каждом конкретном случае требуют подробного анализа, однако можно предварительно сказать, что тогда, когда проблематика литературного произведения выходит далеко за рамки тех мест, где протекает действие, там сеттинг уходит на второй план, как сменная декорация. Что-то большее есть и в Гамлете, и в Мышкине, что позволяет им находить новые места постоянного или временного обитания. Их человеческое измерение и связанные с ними вечные вопросы земного бытия столь далеко выходят за рамки времени и места, которые закреплены за ними литературными первоисточниками, что вряд ли эти персонажи слишком много потеряют от перемещений во времени и в пространстве кинематографа, если будет в них угадано главное.

Другое дело, когда место действия произведения литературы имеет принципиальное значение, и от перемены его утрачивается бо́льшая часть смысла, искажаются характеры и судьбы героев.

В сентябре 2012 года состоялась премьера британского телесериала «Дамское счастье» совместного производства телекомпаний ВВС и Masterpiece, рассказывающего о буднях большого универмага и о страстях, которые обуревают его сотрудников и покупателей. Сериал стал адаптацией одноименного романа Эмиля Золя, действие которого происходит в Париже и рисует судьбу бедной провинциалки, приехавшей в столицу и поступившей продавщицей в универсальный магазин с броским названием «Дамское счастье» - один из тех, что создавались во французской столице в 1870-е годы. Роман с захватывающим сюжетом о любви богатого красавца-хозяина магазина к бедной молоденькой продавщице из провинции протекает под звуки гимна первому универсальному магазину XIX века с подробным описанием его работы и с восторгами по поводу французского вкуса и парижского шика.

Британская адаптация переносит действие картины из Парижа в Северо-Восточную Англию 1890-х, словно не видя различий между торговлей женским модным платьем во французской столице и этим же занятием в английской провинции, будто нет разницы между парижскими модницами 
и чопорными консервативными англичанками, полагающими, что парижские модные салоны - это гнезда разврата. Авторы картины (Дэвид Друри, Марк Йобст, Сьюзен Талли) вынуждены были в связи с переменой места действия поменять героям национальность, гражданство, имена: вместо француза Октава Муре - возник англичанин Джон Моррей (Иман Эллиотт); вместо Денизы Бодю - Дениз Ловетт (Джоэнна Вандерхам), вместо мадам Орели - мисс Одри и т.д. и т.п.

Цель Октава Муре в романе Золя - повергнуть к своим стопам Париж и обуздать стихию предпринимательства; цель Джона Моррея - захватить улицу, обанкротить мелкие лавчонки и стать здесь самой крупной торговой точкой. Цель героини романа Золя Денизы Бодю, потерявшей работу у себя дома, - во что бы то ни стало найти ее в столице, чтобы зарабатывать на жизнь для своих младших братьев-сирот, которых ей, после смерти родителей, приходится содержать одной. Цель героини сериала, которая переехала из одной английской провинции в другую, найти хорошее интересное место, где она расцветет и, быть может, найдет свое счастье. Сериал обошелся без семьи разорившегося дяди героини, без ее братьев, которым она заменила мать, без отчаянной нищеты девушки, вынужденной каждый вечер после работы чинить свои старые башмаки, а крохотные заработки откладывать на содержание своих мальчиков, Жана и Пепе.

Экранизация «по мотивам», лишенная своей исконной почвы, явно преследовала лишь развлекательную цель, не обременяя себя большими смыслами французского романа. На костях разоряющихся мелких лавочников возникает огромное капиталистическое предприятие, и весь ход конфликта у Золя представлен так, что справедливость остается на стороне теснимых. Они побеждены в неравной борьбе, уничтожены фактически, но морально торжествуют. Золя создал образ сильной личности, коммерческого гения, чей успех обусловлен пониманием новых задач, стоящих перед торговлей. Нельзя помешать триумфу эпохи предпринимательства, но нельзя не сострадать и ее жертвам, обреченным на гибель. Роман Золя заканчивается для его главных героев вполне счастливо. Героиня, Дениза Бодю, понимает, что хозяин влюблен в нее, но избегает стать его очередной любовницей.

Я поклялась не выходить замуж; не могу же я привести вам с собою двух детей, не правда ли?

- Они будут и моими братьями... Ну скажите же «да», Дениза!

- Нет, нет, оставьте меня, вы меня мучаете! 
Мало-помалу силы его иссякли. Это последнее препятствие сводило его с ума. Неужели даже такою ценой невозможно добиться ее согласия? Издали до него долетали говор и шум трехтысячной армии служащих, ворочавшей его царственное богатство. Да еще этот нелепый миллион лежал тут! Это было нестерпимо, как злая ирония, - и Муре готов был вышвырнуть его на улицу.

- Так уезжайте же! - крикнул он, и слезы хлынули у него из глаз. - Поезжайте к тому, кого вы любите... Все дело ведь в этом, не правда ли? Вы меня предупреждали, я должен был помнить это и не мучить вас напрасно.

Она была ошеломлена его безудержным отчаянием. Сердце у нее разрывалось. И с детской стремительностью она бросилась ему на шею, тоже рыдая и лепеча:

- Ах, господин Муре, да ведь вас-то я и люблю!

Впереди - свадьба, и Муре обещает своей избраннице, что после месяца в провинции (нужно время, чтобы затихли сплетни) она вернется в Париж с ним об руку полновластной владычицей его торговой империи. Роман Золя поведал о времени перемен, очень тяжелых для многих персонажей, о любви, которая находит в себе силы пережить все невзгоды, о героине, которая смогла их преодолеть и остаться верной себе.

Сериал «по мотивам» «Дамского счастья», сохранив все же некоторое сходство с первоисточником, получил неплохие рейтинги. Казалось бы, на этом и надо остановиться. Но не тут-то было. Дорожа только рейтингами, но никак не репутацией авторов картины и тем более не киносудьбой романа Золя, ВВС продлил сериал на второй сезон: был написан сценарий как бы в продолжение романа, придуманы новые обстоятельства, сочинены интриги, задействованы препятствия; некоторым героям поменяли возраст, пол, семейное положение, социальный статус; замужние дамы стали вдовами, их живые мужья чьими-то любовниками, дочери - юношами в поисках богатых вдов.

Процитирую зрительский отклик. «Сценаристы сериала книгу не читали, им ее рассказали приятели за чашкой чая. И они решили, что это неплохая почва для их бурных фантазий. Да, сериал неплох, его щедрый бюджет нескромно проглядывает в красивых костюмах и роскошных интерьерах. Вот только от Золя в нем ничего не оставили, лишь легкий намек. Старую потертую книгу с гравюрами ручной работы по сложившейся традиции заменили ярким красивым глянцевым комиксом. Никакой глубины характеров, никакого надрыва и полноты чувств, который так присущ персонажам Золя. Никакого сияющего и щемящего счастья и ослепитель- 
ного блеска нового уклада, построенного на сломанных костях старого» [«А счастье было так возможно...»].

Несомненно: это точка зрения литературоцентричного зрителя. Только такой зритель может почувствовать разницу между старинной книгой с гравюрами ручной работы и ярким глянцевым комиксом.

Но вот альтернативный взгляд.

Очень часто создатели пытаются сделать лучше из того, что было. Показать то, что вызовет всеобщий восторг. Это далеко не всегда удается... Фильм - это продукт крайне субъективный, а если писатель создает свое творение как божественный дар, как чадо вдохновения, как пророчество, то режиссер воспринимается как человек, который исключительно портит этот дар. На этот раз камень в огород режиссеров был брошен на почве сильного искажения сюжета произведения. Хорошо это или плохо? Можно ли брать на себя право менять сюжет, вторгаться в произведение, в «пророчество» великого писателя и что-то менять бестолковыми режиссерскими манипуляциями? Почему бы и нет? Ведь книгу читали все. У всех уже появились определенные выводы и фантазии на представленные темы. Почему бы не изменить концепцию сюжета? Это не смертельно. Это просто режиссерский субъективный взгляд на произведение. Ведь у каждого есть свое мнение. Почему бы не оторваться от присущего многим консерватизма и идеализации художественного произведения и рискнуть «исказить» какие-то части сюжета? Мне кажется, придираться по поводу изменения сюжетной части - это слишком жестоко [yarkovskaya84].

В современной культуре эти две точки зрения - литературоцентричная, она же «консервативная», и «интерпретационная», она же «прогрессивная», - сосуществуют, иногда мирно, иногда - скандально. Согласно первой позиции - приоритетно художественное произведение, так что равнение в экранизации на него. Согласно второй - всегда возможно оторваться от первоисточника, который совсем не нужно идеализировать; напротив, надо рисковать, не боясь исказить его согласно собственному разумению.

Те, кто рисковал, выстраивая второй сезон «искаженного» «Дамского счастья», созданного по произвольному сценарию, но со слабой привязкой к роману Золя (названию, героям, коллизии), ошиблись в главном: они сделали сериал не о тяжелых временах и их преодолении, не о любви, которая способна все выдержать и победить, а о большом магазине (здесь он называется «The Paradise»), о товарах, которые хорошо продаются, о людях, который в этом магазине работают. «Искажения» не пошли на пользу сериалу: ставка на рейтинги провалилась, и в начале 2014 года телеканал объявил, что третьего сезона не будет. Ставили на коммерческий успех, 
дерзко оторвавшись от литературного материала, но подвела именно коммерция: зритель почувствовал и подлог, и подвох. «Дамское счастье» уступило место другим, более удачливым сериалам.

Замена Франции на Англию, французского «Дамского счастья» на британский «The Paradise», старинной книги с гравюрами на гламурный комикс, серьезного сюжета на развлекательную историю стали игрой на понижение и проигрыш. Есть случаи, когда замена места действия при переносе литературы на киноэкран может обессмыслить литературу: так, нельзя отменить в «Гамлете» Эльсинор, нельзя отменить обстановку вишневого сада в пьесе Чехова.

\section{II}

Литературный герой произведения со своим характером и психологией, со всеми своими переживаниями, чувствами, стремлениями, мотивами поступков, поведенческой стратегией - это то неотъемлемое, что не должно подвергаться серьезным изменениям при любой экранной или сценической адаптации. Притом, что его внешность - это только инструмент создания образа: артисты в роли Гамлета или роли Мышкина, будучи внешне не похожи друг на друга, должны сохранять нечто базовое, характерное, присущее только этим героям. Приемом узнавания героя становится система мотивов, связанных с ним. Его поступки, их причины и следствия, свойства характера, неизменные и изменяемые качества личности, стиль высказываний, темы и строй речей, сочувствие к нему или неприятие его все это работает на узнавание. Герой - лицо, к которому, по воле автора, приковано внимание и читателя, и зрителя, и это условие существования произведения.

В художественном мире герой - это лицо, наделенное, кроме внешности, пола и возраста, внутренним содержанием. Это не пассивный наблюдатель, но реально действующее лицо, образ человека, воплощающего характерные черты реальности. Главная задача героя - воплотить художественные смыслы. Как носитель содержания, выражающего замысел автора, он становится печатью эпохи, оставляет моментальный снимок бытия.

Можно ли в киноадаптациях игнорировать содержание, вложенное в понятие «герой»? Ответ в любом случае будет отрицательным. Образ героя, наполненный внутренним смыслом, - это тот неотъемлемый элемент целого, который обеспечивает узнаваемость исходного литературного материала. Невозможно, экранизируя, например, «Гамлета», лишить его монолога «Быть или не быть», убрать из сценария рисунок отношений с Офе- 
лией, Горацием или королевой Гертрудой, матерью Гамлета. Невозможно, без потери смысла романа, поменять местами в экранизации «Евгения Онегина» Татьяну и Ольгу.

Теория литературы различает термины «герой» и «персонаж». Герой обладает неповторимой индивидуальностью и характером, без героя нет картины бытия, он незаменим и не устраняем из киноповествования. Персонаж, если он тоже обладает характером и индивидуальностью, а не просто «работает» статистом, - неотъемлемый элемент адаптации: нельзя устранить из экранизации «Преступления и наказания» не только Соню Мармеладову, но и ее отца, а также таких персонажей, как старуха-процентщица или ее сестра Лизавета. Невозможно упрощать сложность характеров, стремясь маркировать их знаками плюс или минус. Разделение героев на положительных и отрицательных часто бывает весьма условным, требующим серьезного комментария. В сложном характере сгущается парадоксальность жизни, ее противоречивость; в нем концентрируется все самое загадочное и странное, что составляет тайну человека.

Особенно ярко индивидуальность литературного героя отражается в его имени. С выбора имени начинается бытие героя в литературном произведении - и в его экранных и сценических адаптациях. В имени сосредоточивается его внутренняя жизнь, с именем героя ассоциируется огромный пласт ассоциаций и представлений. Бессмысленно заменять имя главного героя на другое, по выбору режиссера - такая замена лишит мир произведения оси координат. В интересах любой экранной или сценической адаптации литературного источника во что бы то ни стало сохранить эту ось.

Стоит задуматься, почему самое известное, хрестоматийное произведение русской классики, «энциклопедия русской жизни» (В.Г. Белинский) - роман в стихах А.С. Пушкина «Евгений Онегин» - фактически не было перенесено на киноэкран. Можно назвать только немую черно-белую игровую картину Василия Гончарова (1911) производства А. Ханжонкова и $K^{\circ}$ по мотивам одноименной оперы П.И. Чайковского по роману Пушкина (в роли Онегина выступил Петр Чардынин) и несколько экранизаций оперы $(1958,1994,2002,2007)$. Если к тому же вспомнить, что «Анна Каренина», например, переносилась на киноэкран более 30 раз, начиная с 1910 года, в России, СССР, Германии, Франции, Италии, Венгрии, США, Великобритании, Аргентине, Бразилии, Индии (а в некоторых странах, включая Россию, США, Великобританию, Италию, Францию, по несколько раз), имеет смысл разобраться в причинах фактического отсутствия киноверсий романа Пушкина на отечествен- 
ном и мировом экранах. Повторю попутно: экранизирован едва ли не весь прозаический и драматургический Пушкин - от «Пиковой дамы» и «Повестей Белкина» до «Бориса Годунова».

Казалось бы: в центре романа - любовная история; кинематографичнее сюжета нельзя и вообразить. Но как экранизировать «энциклопедию» - роман, из которого можно узнать практически всё об эпохе первой четверти XIX века: о вкусах, интересах, ценностях, пристрастиях, чтении, искусстве, модах, лицах? Как совместить в одном киноповествовании крепостную деревню, барскую Москву, светско-имперский Санкт-Петербург, городские дворянские салоны и помещичьи усадьбы? Как рассказать о происхождении, семье, воспитании, образовании, столичном образе жизни Онегина (с любовными интригами и модными развлечениями) до его переезда из Петербурга в деревню, к умирающему дяде?

Кроме того, «Евгений Онегин» - роман в стихах. Возможно ли представить себе, что весь фильм герои будут объясняться четырехстопным ямбом? И как быть с лирическими отступлениями, с вкраплениями от автора и его активным присутствием в тексте? В кино непременно нужны диалоги персонажей: как их сочинить для экранизации романа в стихах? Писать диалоги онегинской строфой - но кто может совершить подобный труд $3 a$ Пушкина? Выбор - или писать монологи стихами на уровне Пушкина или переводить стихи Пушкина в прозу. Утраты в любом случае были бы сокрушительны.

Уместно процитировать высказывание Ю.М. Лотмана о «Евгении Онегине» как о «трудном» произведении.

Самая легкость стиха, привычность содержания, знакомого с детства читателю и подчеркнуто простого, парадоксально создают добавочные трудности в понимании пушкинского романа в стихах. Иллюзорное представление о «понятности» произведения скрывает от сознания современного читателя огромное количество непонятных ему слов, выражений, фразеологизмов, намеков, цитат. Задумываться над стихом, который знаешь с детства, представляется ничем не оправданным педантизмом. Однако стоит преодолеть этот наивный оптимизм неискушенного читателя, чтобы сделалось очевидно, как далеки мы даже от простого текстуального понимания романа. Специфическая структура пушкинского романа в стихах, при которой любое позитивное высказывание автора тут же незаметно может быть превращено в ироническое, а словесная ткань как бы скользит, передаваясь от одного носителя речи к другому, делает метод насильственного извлечения цитат особенно опасным. Во избежание этой угрозы роман следует рассматривать не как механическую сумму высказываний автора по раз- 
личным вопросам, своеобразную хрестоматию цитат, а как органический художественный мир, части которого живут и получают смысл лишь в соотнесенности с целым. Простой перечень проблем, которые «ставит» Пушкин в своем произведении, не введет нас в мир «Онегина». Художественная идея подразумевает особый тип преображения жизни в искусстве. Известно, что для Пушкина была «дьявольская разница» между поэтическим и прозаическим моделированием одной и той же действительности, даже при сохранении той же тематики и проблематики [Лотман].

Нечего и говорить о тех «добавочных трудностях», которые могли бы возникнуть при переводе поэтического языка романа на язык кино. Есть, конечно, опыт оперы П.И. Чайковского (1877-1878) на либретто Константина Шиловского, которая сосредоточилась на мелодраматической истории любви (сначала отвергнутой, потом запоздало испытанной, в финале безнадежной) Онегина и Татьяны. Здесь ведь сама музыка, арии, дуэты, речитативы отчасти заменили пушкинский стих и примирили с неизбежными упрощениями грандиозного литературного произведения.

Кинофильм «Евгений Онегин», кто бы его ни снял, был бы обречен на опустошительный эффект: никакой «энциклопедии», никаких лирических отступлений и никакого Пушкина, который и сам был одним из героев своего романа, никакой многозначности и многоплановости. Понимая все это, отечественные кинематографисты за столетие с лишним существования большого кино так и не отважились на эксперимент.

\section{III}

Но эксперимент все же состоялся: в 1999 году на экраны вышел «Онегин», британско-американская вольная интерпретация пушкинского романа, снятая режиссером Мартой Файнс [«Онегин»: 1998], где в роли Евгения Онегина выступил ее брат, актер Рейф Файнс. Отечественные критики и зрители отнеслись к замыслу (его много лет вынашивал актер, мечтавший о роли Онегина) как к опасной авантюре - дескать, как могут иностранцы даже помышлять о «нашем» «Онегине». Но замысел воплотился, и все увидели, что герои изъясняются прозой, и только письма цитируются стихами.

Просмотр картины в России превратился в охоту за погрешностями, анахронизмами, несоответствиями, из-за которых она была названа «клюквой». Краткий перечень ошибок будет полезен хотя бы для пони- 
мания того, что к экранизациям своей классики у нас подходят не только с биноклем, но с лупой и микроскопом.

Первое, что резало ухо российскому зрителю, - музыкальный фон: он совершенно не соответствовал онегинскому времени (1819-1825 годы). В картине звучали: вальс «На сопках Маньчжурии», написанный в 1906 году; песня «Ой, цветет калина в поле у ручья», написанная в 1950 году Исааком Дунаевским для фильма «Кубанские казаки»; мелодия песни «Ой, полным-полна коробушка» на стихи Н.А. Некрасова (1861), написанная Я.Ф. Пригожим в 1898 году; вальс на петербургском балу у Татьяны и ее мужа из оперы А.Н. Верстовского «Аскольдова могила» (1835).

Музыкальное оформление, выбранное Магнусом Файнсом, братом главного актера Рейфа Файнса и его сестры, режиссера Марты Файнс, стало, по мнению критиков и зрителей, откровенным ляпом и сильно подорвало доверие ко всему замыслу.

Большие претензии предъявлялись и к построению сюжета: к отсутствию в картине сцен, которые есть в романе, к добавлению «лишних» сцен, которых в романе нет, к перемещению сцен из одного эпизода в другой. Не прощались слезы, которые в картине пролил Онегин над телом убитого им Ленского, то есть слезы, которых в романе не было, или слезы в финальной сцене объяснения Татьяны с Онегиным, тогда как в романе она оставалась внешне спокойной. Не звучал закадровый голос автора (Пушкина), который мог бы помочь раскрытию образов.

Как можно видеть, зрители и часть критического сообщества рассуждали о британско-американском «Онегине» придирчиво, с буквалистских позиций, игнорируя и проблемы киноязыка, и специфику режиссерского видения, и актерские ракурсы. Немало нареканий прозвучало и по адресу актерской пары - Рейфа Файнса и Лив Тайлер. Почему вообще Рейф Файнс мечтал об Онегине и таки добился этой роли? Он играл Красного Дракона, герцога Девонширского, тирана и деспота, Волан-де-Морта и многих других уродов и темных подлецов. Он и Онегина сделал циником и мрачным мизантропом. Его петербургские приятели, такие же испорченные, как он сам, рассуждают об «экзотических вкусах» Онегина, считая его повесой из повес, и он, дабы оправдать репутацию, признается, что обладал некой светской дамой «однажды на пари». «Я не могу больше ее себе позволить», - говорит Онегин о дорогой куртизанке, которую навестил (плотоядно лизнув большой палец ее обнаженной левой ноги) перед отъездом из Петербурга. Он жесток и насмешлив с Ленским, своим юным соседом-поэтом, он холоден с деревенской Татьяной и настойчиво домогается Татьяны замужней, ибо чрезмерно самолюбив, эгоистичен и никогда ни 
в чем не знает отказа. Он байронически мрачен, во всех сценах выглядит как скучающий и всех презирающий эгоист и даже в финале, глядя на Татьяну и требуя от нее любовных признаний, не может отрешиться от своего одновременно алчного и тоскующего взгляда.

Серьезный упрек прозвучал и в адрес Татьяны - за то, что она якобы поддалась мужскому напору Онегина. «В финале, при решающей между ними сцене, она горячо и зареванно признается ему в любви... Как много слов, объяснений, повторений, слез и соплей... Зачем?.. Где неприступность, где тонкость игры, с помощью которой мы должны догадываться о таящихся под неприкосновенной верностью мужу чувствах, но до последнего сомневаться? Пушкин одной горячей, но краткой фразой “но я другому отдана и буду век ему верна” заменил бы весь этот бред и словоблудие!» [Маклацкая].

Между тем сцена объяснения Татьяны в финале вряд ли может быть названа уступкой замужней женщины влюбленному в нее напористому мужчине, к тому же еще родственнику (кузену) мужа. Диалог Татьяны и Онегина, сыгранный в весьма чувствительной манере (русский перевод точно соответствует английскому оригиналу), не дает почвы для такого вывода, тем более, что ведь у Пушкина есть эта самая строка: «Я вас люблю, к чему лукавить...»

Татьяна и не лукавит: признание, которое запоздало вырвет у нее Онегин, мучительно, но уже бесполезно.

- Скажите, что любите меня. Солгите мне...

- Я вас люблю, да. Я вас люблю. Но я другому отдана и поклялась хранить ему верность. Я сдержу свою клятву. Идите. Да, идите, оставьте меня, пожалуйста. Пожалуйста. Мы не должны больше видеться. Прошу вас. Не возвращайтесь. Не приходите больше сюда. Пожалуйста. Простите меня, простите.

Слезы Татьяны, за которые упрекают Лив Тайлер, кажутся здесь вполне уместными, как и сцена ее нежностей с мужем (Мартин Донован); у Пушкина этот важный генерал не имеет фамилии, здесь же он князь Никитин. Зрители, однако, не терпят ничего, что выходит за рамки романа: «много внимания уделяется отношениям Татьяны с мужем. Хотя в романе, как мы помним, он вообще как персонаж особенно не фигурирует. Но в фильме они до того подробны, что мы видим, как муж наблюдает за читающей письмо от Онегина Татьяной, которое она на его глазах рвет и отправляет в горящий камин» [Маклацкая]. Категорически не нравятся и наставления матушки Татьяны и ее тетушки, вынуждающих девушку «проявить» себя 
в столице: «Если ты не выйдешь замуж, останешься старой девой. Или станешь куртизанкой». Не согласны зрители и с внешностью главных героев: Онегин староват, а у Татьяны (Лив Тайлер здесь изумительно красива) почему-то темные волосы и карие глаза, в то время как она должна быть сероглаза и русоволоса. Вообще фильм, по мнению зрителей, страдает от недостатка русскости - ее нет ни в декорациях, ни в костюмах героев, ни в пейзажах. Вывод скептиков звучал категорично: ничего общего с романом Пушкина нет - другая культура, нет понимания тонкостей, полутонов, зря англичане за это взялись. Хотя вряд ли и русская экранизация смогла бы передать все изящество и красоту «Онегина».

Впрочем, мнения, как и всегда при оценке экранизаций, разделились.

Обобщая зрительское восприятие «Онегина», можно резюмировать:

Во-первых, российские зрители, крайне ревниво относясь к зарубежным экранизациям отечественной классики, куда более терпимы к отечественным экранизациям зарубежной классики.

Во-вторых, ревность к своей классике проявляется, как правило, в требовании неукоснительного соблюдения точности в содержании и форме произведения: не прощаются отклонения в сюжете и фабуле, во внешности персонажей, в костюмах, декорациях, музыкальном оформлении. «Не похоже на оригинал» - основной критерий зрительской критики.

В-третьих, зрители с более широким взглядом, без буквалистских представлений об экранизациях, все же смогли оценить трепетную красоту картины, искренность и увлеченность артистов, глубокую любовную драму героев, снятую без пошлости и стремления поставить все с ног на голову. Благодарные зрители писали: хорошо, что Онегин живет в своем времени и в своем городе (съемки многих сцен действительно проходили в Санкт-Петербурге); хорошо, что сюжетная канва романа добросовестно сохранена и авторы картины из соображений дурного осовременивания не заставили, например, Татьяну бежать с Онегиным за границу в начале фильма или согласиться на адюльтер в конце фильма (тогда бы это была не Татьяна Ларина, а Анна Каренина); хорошо, что создатели фильма не поскупились на костюмы и декорации; хорошо, что хотя бы изредка в картине звучит пушкинский стих и царит пушкинское настроение.

Рэйфу Файнсу и его семье, что делали фильм, - писала зрительница, стоит сказать спасибо хотя бы за то, что, поставив перед собой трудновыполнимую задачу, они подошли к ней с должным вниманием и, стоит сказать, сделали все, что могли, используя в первую очередь собственное видение «Евгения Онегина». Фильм о России, снятый иностранцами, пожалуй, это всегда вызывает у нас некоторую снисходительную улыбку, потому что ни 
один иностранец не может прочувствовать всей глубины нашей классики, но в этом случае создатели показали свой взгляд на Онегина, и, что особенно порадовало, отнеслись с должной любовью к оригиналу. И пусть некоторые моменты вызовут у нас скепсис - вроде пейзажа близ дома Татьяны Лариной, но это можно простить, например, за красоту картинки, за цветовое решение фильма, за отсутствие лишней мишуры. Заметно то, что Рэйфу действительно было не все равно, и он интеллигентно, красиво и интересно показал свою трактовку героя. Не скажу, что именно такой Онегин мне виделся, когда я читала Пушкина, но мне понравилось то, что герой у Файнса получился нисколько не отталкивающий. Пожалуй, могу сказать, что я попала под его мрачное очарование... Возможно, если бы наши режиссеры подходили с таким же уважением и любовью к классике, у нас мог бы получится фильм, которому «Онегин» Файнсов не будет конкурентом [Oumi].

В-четвертых, следует все же сказать о профессиональных критиках не только Запада, но и России, которые оценили картину достаточно высоко: она получила призы за лучшую режиссуру и за режиссерский дебют. Британская академия кино и телевизионных искусств (BAFTA) удостоила картину премией за «выдающийся британский фильм 1999 года». Русская гильдия кинокритиков наградила Лив Тайлер призом за лучшую женскую роль в зарубежном кино.

Современный взгляд на образ Онегина выразил в своем русском интервью сам Рейф Файнс, выдающийся актер, который по-человечески не верит, что нужно всю жизнь искать свою единственную любовь, называя эту популярную идею «взаимной пропагандой».

Я во многом солидарен с Онегиным, когда он говорит Татьяне: «Зачем ты пишешь эти письма? Ты не должна так себя вести». Мне всегда казалось, что это оправдано, что это здравый смысл. Не стоит писать любовные письма незнакомому мужчине. Если бы я получил письмо с любовным признанием, я бы думал: что мне с этим делать? какой дать ответ? Но вот, где Онегин играет в игру и манипулирует, это злоупотребление своей властью над женщинами. В нем есть определенная жестокость. Он, правда, получает по заслугам позже [Дарья Златопольская...].

По прошествии почти двух лет после «Онегина» актер признался:

Я, наверное, никогда не делал столько ошибок, сколько мы сделали в этом фильме. Я знаю, что мы искренне старались. Но мне неловко за то, как мы пытались снять «Онегина». Потому что с возрастом я начинаю видеть, как мы были наивны. Мы хотели добиться подлинности по отношению к той эпохе в России, но, конечно, я знаю это, мы сделали множество ошибок. 
По истечении более полутора десятков лет ни в мировом, ни в отечественном кинематографе так и не появилось больше никакого другого Онегина, никакой другой Татьяны. Пересчитав все ошибки, учтя все неточности, огласив все несоответствия и анахронизмы экранизации, отечественный зритель, кажется, все же признал англичан пушкинскими героями - в благодарность за их добрые намерения, за их искренность и, может быть, даже за их наивность.

Мнения же об «Онегине» вроде: «Восхитительный фильм, шедевр мирового кинематографа» и «Умора, пустышка» - во всех опросах стоят обычно рядом. И это нормально: такое соседство позиций, говоря метафорически, движет горами.

\section{IV}

Петербургская повесть молодого Достоевского «Двойник» (1846) за 170 лет своего существования не могла не повлиять и на художественную литературу, и на научные разыскания в области психоанализа, и на мировой кинематограф. Слабый, робкий, простодушный герой-неудачник с его идеей-фикс о самом себе как о более ловком, пронырливом и смелом то есть о своей удачливой копии - до Достоевского волновала Гофмана, Эдгара По и Гоголя. После Достоевского в самой сильной мере идея двойничества, где зловещий двойник получает свободу действий благодаря раздвоению личности, вошла в художественную ткань готического романа шотландского писателя Роберта Стивенсона «Странная история доктора Джекила и мистера Хайда» (1886), который был экранизирован более 60 раз по всему миру.

Самому «Двойнику» повезло в кино много меньше: отдельные мотивы повести Достоевского были использованы в картине Бернардо Бертолуччи «Партнёр» (1968), а также в картине Брэда Андерсона «Машинист» (2004), хотя тема двойничества, пусть и не в привязке к русской повести, разрабатывалась множество раз: «Твин Пикс» (США, 1990), «Двойная жизнь Вероники» (Франция - Польша, 1991), «Доппельгангер» (США, 1992), «Бойцовский клуб» (США, 1999) и др. В 1997 году Роман Полански приступил было к экранизации повести «Двойник», но проект был закрыт в связи с отказом исполнителя главной роли Джона Траволты сниматься в картине. (Актер улетел с места съемок в собственном самолете, заявив в самый последний момент, что готов сниматься в картине, но только с другим режиссером.) 
Осенью 2013 года в мировой прокат вышла британская черная трагикомедия режиссера Ричарда Айоади «The Double» [«The Double». 2013], снятая по мотивам повести Достоевского - по сути дела она стала единственной более или менее адекватной по авторскому замыслу экранизацией «Двойника». В главной роли (героя и его дублера) снялся тридцатилетний американский актер театра и кино Джесси Айзенберг, успевший к тому времени исполнить роль Марка Цукерберга в фильме Дэвида Финчера «Социальная сеть» (2010) и два десятка других ролей.

Действие фильма перенесено в современную Англию и протекает в некой захудалой конторе, занимающейся статистикой и отчетностью (съемки проходили в заброшенном офисе на окраине Лондона), где вот уже семь лет служит простым офисным работником ничем не примечательный молодой человек по имени Саймон Джеймс. На службе его не жалуют, считая бездарным и никчемным сотрудником, родная мать третирует, девушка, в которую он влюблен (Миа Васиковска), и близко к себе не подпускает.

Картина начинается знаковым эпизодом. Саймон едет на службу в пустом вагоне трамвая. Вдруг к нему подходит некий мужчина и со словами: «Вы на моем месте»- жестом показывает, чтобы тот убрался со своего сидения прочь. Саймон недоуменно смотрит по сторонам - в вагоне никого больше нет, все сидения свободны. Но сказать, что во всех трамваях все места обычно общие и ни за кем специально не закреплены, у него не хватает духа. Он встает и уже больше на садится, продолжая ехать стоя, быть может, боясь еще кому-нибудь помешать удобно устроиться в трамвае. Следующий эпизод лишь усиливает впечатление от крайней, доходящей до абсурда, робости. Остановка, двери трамвая открываются, и Саймон, уже приготовившись к выходу, уступает место нескольким входящим пассажирам, которые вносят огромные ящики, по сути дела заблокировав дверь на выход. Он впустил всех, едва успев выскочить из вагона в последний момент, но теперь уже застрял в дверях его кейс-дипломат; дернув его за ручку, он отрывает ручку и остается с ней, но без кейса.

Так, с унизительных неприятностей стартует день героя картины, и это действительно только начало: пропуск остался в дипломате, Саймона долго держит на проходной проверяющий, который прекрасно его знает, и выписывает ему разовый пропуск, исказив фамилию (вместо «Джеймс» «Эймс»). Лифты его не слушают, в ближайшем кафе, куда об обычно ходит поесть, официантка грубит, хамит и обслуживать не хочет. Никакая, даже самая мелкая удача ему не сопутствует, и молва о нем среди сослуживцев и знакомых полностью соответствует его реальному положению: потерянный, одинокий, неприметный, дурно одетый, то ли он есть, то ли его нет. 
Многоквартирный дом, в котором он проживает, такой же серый, мрачный, как и все вокруг, похож на улей с сотами-комнатами для жильцов; единственное развлечение Саймона, которое он может себе позволить, это подглядывание за девушкой, живущей в такой же комнате в соседнем корпусе напротив: подзорная труба-телескоп всегда направлен на окно Ханны, в котором можно разглядеть, чем и кем она занята. Ханна - сослуживица-копировальщица, Саймон видит ее ежедневно, но подружиться, сблизиться, тем более завязать отношения у него тоже не хватает духу.

Физическое и моральное прозябание Саймона усугубляется еще больше, когда в контору, где он работает, приходит новый сотрудник по имени Джеймс Саймон - внешне похожий на Саймона Джеймса, как две капли воды. При этом копия, в отличие от оригинала, - полная ему противоположность: всегда знает, чего хочет, и умеет добиться желаемого, самоуверен, нахален, развязен, прост в обращении - так что и девушки, и руководство конторы принимают новичка в свои тесные объятия.

Дублер очень скоро понял все выгоды своего положения - и начал захватывать территорию за территорией. Сначала копия присваивает себе черты личности оригинала («меня нет в своем теле», «через меня можно дотронуться до стены», «я ненастоящий, деревянный, будто Пиноккио»), потом успешно соблазнил Ханну, затем присвоил себе служебный отчет Саймона, над которым тот долго корпел (и отчет произвел на начальство самое благоприятное впечатление - большой босс, никогда не отличавший Саймона, даже поставил Джеймса ему в пример), отнял у Саймона ключ от его комнаты, чтобы водить туда своих многочисленных подруг. Он даже пришел под видом сына на похороны матери Саймона, и тот, рассвирепев, ударил наглеца в нос. Но кровь пошла и из носа самого героя.

Потери огромны: брошенная Джеймсом Ханна, беременная и больная, пыталась отравиться и еле выжила, Саймона уволили с работы за ненужность - его потерянность и одиночество приводят его на край жизни. «Он украл мое лицо», «я призрак; человек должен быть кем-то, а не призраком» - эти и подобные мысли приводят Саймона к неотступной мысли о самоубийстве, которое он уже наблюдал однажды: некий доходяга тоже не сумел справиться с жизнью, вышел в окно своего высокого этажа, стал на карниз, спрыгнул вниз и разбился.

До самого финала британская картина движется как будто по следам повести Достоевского, так что его выражение «человек-ветошка», существо, беззащитное перед лицом враждебного мира, вполне применимо к неудачнику Саймону, жизнь которого его двойник прибирает к рукам. Однако финал картины резко расходится с концепцией повести: Саймон, 
доведенный до отчаяния, не смиряется. Напротив, он бунтует и решается на экстраординарный поступок. «Я человек, я существую!», - говорит он себе, и это не пустые слова. Однажды он уже потребовал от двойника публично признать, что тот присвоил чужую работу, назвал Джеймса самозванцем, укравшим его лицо, но ничего не добился, кроме собственного увольнения.

Теперь он устраивает все иначе. Во-первых, приковывает двойника наручниками к кровати в своей квартире, а сам, предварительно позвонив в полицию, прыгает с того же самого места, откуда прыгнул неизвестный самоубийца. Но прыгает не прямо на асфальт, как сделал безымянный разбившийся самоубийца, а на тент. За Саймоном приезжает карета скорой помощи и спасает его, а двойник Джеймс умирает на кровати от потери крови. В машине рядом с Саймоном сидит Ханна, которая, наконец, смогла оценить его редкие качества. Здесь же находится и большой босс, который говорит Саймону, что он «редкий человек». Саймон, улыбаясь, отвечает: «Мне хочется верить, что уникальный».

Так история медленного и необратимого сумасшествия забитого и загнанного в угол маленького человека трансформировалась в сюжет о границах терпения потерянного существа и о его способности радикально отомстить обидчику: за минувшие полтора столетия убогие и никчемные, робкие и забитые персонажи осознали свои суверенные права на жизнь и готовы отстаивать их любой ценой. Психопатология преобразовалась в криминальную историю, и неизвестно, как могло бы пойти расследование одного преступления - ведь палач и жертва поменялись местами. Увидит ли воображаемое следствие по делу Саймона Джеймса смягчающие обстоятельства, облегчат ли они участь убийцы, кем - увы! - стал этот робкий, застенчивый офисный служащий, все это вопросы риторические и должны быть вынесены за скобки фильма Ричарда Айоади «The Double».

Яков Петрович Голядкин, герой повести Достоевского, - существо бесконечно трагическое, у которого не хватило ни сил, ни характера вырваться из цепких лап хищного двойника, захватчика с амбициями. В мире «Двойника» Достоевского возможность подлой замены слабой, но суверенной личности другой личностью, морально беззастенчивой и коварной, оказалась осуществима: оригинал уступает копии (дублеру, «неблагопристойному близнецу») свои человеческие права, суверенитет и место в жизни. «Человеку-ветошке» предавшее его общество оставляет только один выход - клиническое безумие, вместе с «казенной квартирой, дровами, с лихт и с прислугой» [Достоевский 1972-1990: I, 229], то есть с палатой для ду- 
шевно больных, куда отвозит несчастного Якова Петровича доктор медицины и хирургии Крестьян Иванович Рутеншпиц. Мысль о наказании злорадствующего близнеца-дублера, Голядкина-младшего, которая приходит в голову Голядкину-старшему, связана с новым унижением: пасть в ноги начальству, предать свою судьбу в его руки, умолять, чтоб не погубил, чтоб спас от развращенного злодея и отменил безбожную, самовольную подмену. «Он другой человек, ваше превосходительство, а я тоже другой человек; он особо, и я тоже сам по себе...» [Достоевский 1972-1990: I, 213].

Современный англичанин, житель Лондона, тоже ставший жертвой наглой подмены, выбирает кардинально другой путь - не просит, не умоляет, не унижается перед сильным, а убивает обидчика и сам становится, как ему кажется, сильнее сильного. То есть жестоким, торжестующим убийцей.

При всей схожести сюжета - другое время, другое место, другой человеческий стержень. И другой финал, которого нет и не может быть в контексте «Двойника» Достоевского.

\section{Список литературы}

1. «А счастье было так возможно...» Рецензия // [Электронная версия]. URL: http:// www.kinopoisk.ru/film/709266/vk/1/ (дата обращения 15.02.2017).

2. Дарья Златопольская в диалоге с Рейфом Файнсом. Белая студия / [ [Электронный реcypc]. URL: http://tvkultura.ru/video/show/brand_id/20927/episode_id/1151448/ video_id/1112246 (дата обращения 18.05.2015).

3. Достоевский Ф.М. Полное собрание сочинений: В 30 т. Л.: Наука. 1972-1990.

4. Лотман Ю.М. Роман в стихах Пушкина «Евгений Онегин». Спецкурс. Вводные лекции в изучение текста. Памяти Бориса Викторовича Томашевского (К 85-летию со дня рождения). Введение // [Электронный ресурс]. URL: http://pushkin.niv.ru/pushkin/ articles/lotman/evgenij-onegin/onegin.htm (дата обращения 18.05.2015).

5. Маклащкая E. Междусобойчик семьи Файнс // [Электронный ресурс]. URL: http:// www.kinopoisk.ru/film/5528/ (дата обращения 18.05.2015).

6. «Онегин». 1998 // [Электронный ресурc]. URL: http://yandex.ru/video/search?t ext=\%D0\%BE\%D0\%BD\%D0\%B5\%D0\%B3\%D0\%B8\%D0\%BD\%20\%D1\%84\%D 0\%B8\%D0\%BB\%D1\%8C\%D0\%BC\&path=wizard\&filmId=26kwWwQC0Cw （дата обращения 18.05.2015). Цитаты из фильма приводятся по экранной версии.

7. «The Double». 2013 // [Электронная версия]. URL: http://hdrezka.me/films/ drama/1594-dvoynik.html (дата обращения 18.04.2017).

8. Оuті. Английский взгляд // Там же.

9. yarkovskaya84. Рецензия // http://seasonvar.ru/serial-8071-Damskoe schast_e-2-season.html (дата обращения 15.02.2017). 